\title{
MANAGEMENT OF BURN WOUNDS BY COMPOUND AYURVEDIC PREPERATION CHANDANADI YAMAKAM
}

\author{
Kishor Kumar KH*, Kumar TP, Ksheera Sagar TD², Gurumurhty ${ }^{3}$ \\ 1. Assistant Professor, J S S Ayurvedic Medical College, Mysore \\ 2. Professor and H.O.D., Govt. Ayurvedic Medical College, Mysore \\ 3. Professor and H.O.D, Dept of Recostructive and Plastic Surgery, Mysore Medical College, Mysore
}

\begin{abstract}
No injury sustained by the man is so frightful with the complications, as the burn wound. Loss of skin with all its protective and homeostatic functions exposes the body to variety of stresses which are not seen in any other type of injury. The topical anti-microbial agents are of at peek importance in this regard. To evaluate the efficacy of the Ayurvedic preparations in the management of Burn wounds, the present study "Management of burn wounds by compound Ayurvedic preparation Chandanadi Yamakam" is conducted. 30 patients having $2^{\text {nd }}$ degree burn with involvement below $15 \%$ of total body surface area (TBSA) were considered for the study and Chandanadi Yamaka is applied twice daily for every three days for 21 days and the changes in the objective and subjective parameters were observed. Significance of the study was assessed by the ' $t$ ' test. Results showed that Chandanadi yamaka is effective in the management of burn wounds.
\end{abstract}

Key words: Burn wounds, Chandandi Yamakam, Burn injury.

\section{Introduction:}

Ever since man has discovered the fire by accidental friction of stone, he is experiencing both advantages and disadvantages of its utility. On one side it is used as main source of energy on the other side it can cause most disastrous effect.

In India more than 10000 burn cases are associated with deaths and over one million moderate to severe burns occur each year. Each year more than 4,000 Americans die as a result of fires and more than 23,000 are injured seriously enough to require hospitalization.

\footnotetext{
*Corresponding author:

Lecurer, J S S Ayurvedic Medical College, Mysore.

E-mail ID: drkkhullatti@gmail.com.
}

In major burn injuries systemic treatment is given more importance than local, where as in minor burn injuries it is always the local treatment.

The available topical antimicrobial applications in the management of minor burn injuries do not give satisfactory relief to the associated features like pain, burning sensation, over whelming exudation etc and none of them influence on rate of healing.

'Chandanadi yamakam' is compound Ayurvedic preparation described as useful in all types of burn injuries in classical texts like "Chakradatta" and "Yogaratnakara".

The drugs explained in the preparation has anti-bacterial, anti-inflammatory, antipyretic and anti-exudative properties and also useful in wound healing, getting normal 
pigmentation of the skin, cooling and retaining normal vascularisation by checking the bleeding.

\section{Materials and methods:}

Patients with complaint of burn wounds available from O.P.D and I.P.D of burns ward, Mysore medical college, Mysore, O.P.D and I.P.D of Govt. Ayurvedic medical college and Hospital, Mysore, and O.P.D and I.P.D of J.S.S Ayurvedic medical college, Mysore after the registration and initial management on the day of burn with clearance of medico-legal aspects were selected for the study. Patients were selected randomly irrespective of their sex, occupation, socio-economic group and religion.

Patients with the history of burn wounds caused by dry heat, open flame and scalds, age group between 5yrs-55yrs, having burns of T.B.S.A. (Total Body Surface Area) of below $15 \%$ and presenting features of $2^{\text {nd }}$ degree burn, involving upper limbs, lower limbs, trunk and face were selected for the study.

Burns caused due to electricity, chemicals, oils and fats, cold and irradiation, patients with systemic diseases, patients showing signs and symptoms requiring emergency care were excluded from the study.

Informed consent was obtained from the patients or from the patient's parents, if they were children.

\section{Drug review: (Figures 8-11)}

The drugs used in this preparation are Pterocarpus santalinus (Raktha chandan), Glycirrhiza glabra (Yasti madu), Rubia cardifolia (Manjista), Woodordia fruticosea (Dhataki pushpa), Caesalpinia sappan
(Patranga), Ficus bengalensis (Vata shringa), Nelumbo nucifera (Prapondarika), Cynodon dactylon (Doorva), Cows ghee (Go gritha), Mustard oil (Tila taila), Cows milk (Go ksheera) and Water.

\section{Preperation:}

All the drugs which are collected from local market and some are freshly collected were made authenticated for its identity and genuinity from Regional research center, Bangalore.

All the drugs were weighed properly one by one and pulverized in to course powder and sewed in a mesh of $1 / 20$ size and weighed again separately. Powdered ingredients were mixed properly one by one and taken in mortar and triturated with water to obtain fine paste, this is mixed with cow's ghee and mustard oil each 2 parts and to this mixture 16 parts of water and 32 parts of milk was added and heated in mild flame. This procedure was carried out for three days, on each day it was boiled for 2-3 hrs. The heating was continued until all the water molecules were evaporated.

\section{Physical and Chemical Analysis of} Chandanadi Yamakam (Figures 12)

Physical and chemical analysis was done in 'Central pharmacy', Bangalore.

Ingredients:- Pterocarpus santalinus, Glycyrrhiza glabra, Rubia cardifolia, Cynodon dactylon, Woodfordia fruticosa, Nelumbo nucifera, Caesalpinia sappan, Ficus bengalensis, Sesamum oil, Ghee and Milk.

Description: - A yellowish-brown coloured oily liquid of pleasant odour

\begin{tabular}{|lll|l|l|}
\hline $\begin{array}{l}\text { Loss on drying at } \\
110^{0} \mathrm{C}\end{array}$ & $:$ & $\begin{array}{l}\text { Round } \\
\mathrm{w} / \mathrm{w}\end{array}$ \\
\hline $\begin{array}{l}\text { Refractive index at } \\
40^{\circ} \mathrm{C}\end{array}$ & $:$ & 1.4680 & \\
\hline
\end{tabular}




\begin{tabular}{|l|c|l|}
\hline Acid value & $:$ & 206.2656 \\
\hline Iodine value & $:$ & 91.7095 \\
\hline Ester value & $:$ & 201.1280 \\
\hline Wt. per .ml & $:$ & $0.9106 \mathrm{Gms}$ \\
\hline
\end{tabular}

\section{Methodology:}

Initially patient was given wash with tap water and pears soap on the first day of treatment over the affected area. Then the surrounding part of the wound was cleaned with savalon liquid and then it was wiped with dry cotton. Sufficient quantity of Chandanadi yamakam was applied over the wound with the sterile cotton swab held by sterile artery forceps and ensured that it spreads uniformly all over the surface of the wound.

Patient was advised to apply Chandanadi yamakam twice daily once in the morning and once in the evening. Patient was instructed to fallow the same method employed on the first day of treatment in the hospital.

After the application of Chandanadi yamakam over the wound, patients were advised to keep the wound uncovered but not to expose the wound to dirty surroundings or contact with any materials like soil, dust etc.

Patients were advised to have normal diet and habits. Observations on the subjective and objective changes with the treatment were made once in three days for 21 days. Observations were recorded in the proforma of the case sheet prepared for the study. Fallow up observation of 45 days for the development of any post burn complications at the site of lesion like formation of hypertrophied scar and contractures were made.

\section{Criteria for the assessment of result}

\section{Subjective Parametrs}

\section{Pain}

The changes in the pain with the treatment were considered as follows.

The pain which was intolerable, constant and makes to seek medical help as early possible was considered as severe and denoted as- III

Constant, tolerable pain and subject can wait even for some days in seeking medical help was considered as moderate and denoted as -II

The pain which was tolerable, negligible considered as mild and was denoted as I

The absence of pain is considered as nil and denoted as - 0

\section{Burning sensation}

The change in the burning sensation during the treatment was considered as fallows.

The burning sensation which was intolerable, constant and makes the patient seek medical help as earlier possible is considered as severe and denoted as -III

The burning sensation which was constant and tolerable and subject can even for some days in seeking medical help is considered as moderate and denoted as- II

The burning sensation which was tolerable, negligible is considered as mild and denoted as-I

The absence of burning sensation is considered as nil and denoted as - 0 


\section{OBJECTIVE PARAMETERS}

\section{Oedema}

Presence of oedema was denoted as- I

Absence of oedema was denoted as- 0

\section{Discharge}

Presence of discharge was denoted as - I

Absence of discharge was denoted as- 0

\section{Wound healing}

Presence of the raw surface of the wound was denoted as - III

Formation of the crust has been denoted as-II
Separation of the crust and appearance of the granulation tissue was denoted as - I

Complete healing with flat scar was denoted as- 0

Response in the healing was considered as fallows

1. Good healing (G)-Complete healing observed within 15 days

2. Fair healing (F)-Complete healing observed within 21 days

3. Poor healing (P) - Incomplete healing even after 21 days

\section{OBSERVATIONS AND RESULTS (Figures 1-7)}

\begin{tabular}{|c|c|c|c|c|c|c|c|c|c|}
\hline $\begin{array}{ll}\text { Signs and } \\
\text { symptoms }\end{array}$ & $\begin{array}{l}\text { Before } \\
\text { treatment }\end{array}$ & $3^{\text {rd }}$ day & $\begin{array}{l}6^{\text {th }} \\
\text { day }\end{array}$ & $\begin{array}{l}9^{\text {th }} \\
\text { day }\end{array}$ & $\begin{array}{l}12^{\text {th }} \\
\text { day }\end{array}$ & $\begin{array}{l}15^{\text {th }} \\
\text { day }\end{array}$ & $\begin{array}{l}18^{\text {th }} \\
\text { day }\end{array}$ & $\begin{array}{l}21^{\text {st }} \\
\text { day }\end{array}$ & $\%$ \\
\hline Pain & $\begin{array}{l}\text { III-20 } \\
\text { II-10 } \\
\text { I-0 } \\
0-0\end{array}$ & $\begin{array}{l}\text { III-4 } \\
\text { II-15 } \\
\text { I-11 } \\
0-0\end{array}$ & $\begin{array}{l}\text { III-1 } \\
\text { II-6 } \\
\text { I-17 } \\
0-6\end{array}$ & $\begin{array}{l}\text { III-0 } \\
\text { II-4 } \\
\text { I-9 } \\
0-7\end{array}$ & $\begin{array}{l}\text { III-0 } \\
\text { II-1 } \\
\text { I-8 } \\
0-21\end{array}$ & $\begin{array}{l}\text { III-0 } \\
\text { II-1 } \\
\text { I- } 8 \\
0-21\end{array}$ & $\begin{array}{l}\text { III-0 } \\
\text { II-1 } \\
\text { I-4 } \\
0-26\end{array}$ & $\begin{array}{l}\text { III-0 } \\
\text { II-0 } \\
\text { I-0 } \\
0-30\end{array}$ & 100 \\
\hline $\begin{array}{l}\text { Burning } \\
\text { sensation }\end{array}$ & $\begin{array}{l}\text { III-22 } \\
\text { II-7 } \\
\text { I-1 } \\
0-0\end{array}$ & $\begin{array}{l}\text { III-0 } \\
\text { II-16 } \\
\text { I-13 } \\
0-1\end{array}$ & $\begin{array}{l}\text { III-0 } \\
\text { II-0 } \\
\text { I-13 } \\
0-17 \\
\end{array}$ & $\begin{array}{l}\text { III-0 } \\
\text { II-0 } \\
\text { I-0 } \\
0-30\end{array}$ & & 10 & & & 100 \\
\hline Discharge & $\begin{array}{l}\mathrm{I}-22 \\
0-0\end{array}$ & $\begin{array}{l}\mathrm{I}-22 \\
0-0\end{array}$ & $\begin{array}{l}\mathrm{I}-6 \\
0-16\end{array}$ & $\begin{array}{l}\mathrm{I}-0 \\
0-22\end{array}$ & & $x$ & & & 100 \\
\hline Oedema & $\begin{array}{l}\mathrm{I}-30 \\
0-0\end{array}$ & $\begin{array}{l}\mathrm{I}-30 \\
0-0\end{array}$ & $\begin{array}{l}\mathrm{I}-29 \\
0-1\end{array}$ & $\begin{array}{l}\mathrm{I}-15 \\
0-5\end{array}$ & $\begin{array}{l}\mathrm{I}-4 \\
0-26\end{array}$ & $\begin{array}{l}\mathrm{I}-0 \\
0-30\end{array}$ & & & 100 \\
\hline Wound healing & $\begin{array}{l}\text { III-30 } \\
\text { II-0 } \\
\text { I-0 } \\
0-0\end{array}$ & $\begin{array}{l}\text { III-19 } \\
\text { II-11 } \\
\text { I-0 } \\
0-0\end{array}$ & $\begin{array}{l}\text { III-2 } \\
\text { II-28 } \\
\text { I-0 } \\
0-0\end{array}$ & $\begin{array}{l}\text { III-0 } \\
\text { II-14 } \\
\text { I-16 } \\
0-0\end{array}$ & $\begin{array}{l}\text { III-0 } \\
\text { II-3 } \\
\text { I-27 } \\
0-0\end{array}$ & $\begin{array}{l}\text { III-0 } \\
\text { II-0 } \\
\text { I-19 } \\
0-12\end{array}$ & $\begin{array}{l}\text { III-0 } \\
\text { II-0 } \\
\text { I-16 } \\
0-14\end{array}$ & $\begin{array}{l}\text { III-0 } \\
\text { II-0 } \\
\text { I-2 } \\
0-28\end{array}$ & 93.33 \\
\hline
\end{tabular}

\section{Statistical analysis:}

At 29 degree of freedom, 5\% significant limit of ' $t$ ' is 2.05 . The observed ' $t$ ' value is 10.04 times the standard error. This indicates that 'CHANDANADI
YAMAKAM' is effective in the management of burn injuries. 


\section{Discussion:}

Pain was observed in all 30 patients selected for the study before the treatment. All the 30 patients were relieved from pain with in the duration of 21 days of treatment. Regressal of pain may be due to presence of sneha dravya in the preparation. Thus it can be known that use of CHANDANADI YAMAKAM is effective in reducing pain. All the 30 patients had burning sensation on the day of arrival, gradually there was reduction in the burning sensation and came down to nil by $9^{\text {th }}$ day of treatment. CHANDANADI YAMAKAM contains dravyas which have sheetha veerya and so they are useful in reducing burning sensation. Discharge was observed in 20 patients out of 30 selected for the study. By the end of $9^{\text {th }}$ day of treatment course the discharge came down to nil in all 20 patients. It shows CHANDANADI YAMAKAM is effective in reducing discharge from the wound surface. Among the 30 patients who had got the burn wounds $28(93.33 \%)$ patients got completely healed by the treatment at the end of $21^{\text {st }}$ day. All ingredients of CHANDANADI YAMAKAM have got healing property which might have influenced in healing the burn wounds.

\section{Summary and Conclusion:}

The clinical trail was conducted to study the efficacy of "Chandanadi yamakam" in the management of "Burn wounds'. Management was done by exposure method.

Essential Ayurvedic references were compiled under the chapter "Review of literature" along with the suitable references the modern medical science. Materials and methods for the clinical study were fixed suitable to study and understand the effect of
CHANDANADI YAMAKAM in the management of burn wounds.

A preliminary attempt had been made in the present study to evaluate the efficacy of compound preparation CHANDANADI YAMAKAM.

It was observed that management of Burn wounds by CHANDANADI YAMAKAM is very effective with $40 \%$ of good result and $53.3 \%$ of fair results. The result of the treatment with CHANDANADI YAMAKAM is significant and shows authenticity of classical references which mentions that CHANDANADI YAMAKAM is very much useful in the management of burn injury.

Following conclusions were drawn from the clinical study.

1. 'Chandanadi yamakam' is very much effective in the management of burn injuries. Since complete healing with flat scar was formed in $93 \%$ of patients during the study period.

2. The raw materials required for the preparation of CHANDANADI YAMAKAM are easily available in very less cost.

3. This method is very simple, economical, and free from side effects and can be carried in OPD.

4. Use of Chandanadi yamakam has given very good aesthetic outcome with very less post-burn complications like wound contracture and hypertrophied scar.

5. Chandanadi yamakam is very effective in reducing the associated complaints like pain, burning sensation and overwhelming exudation. 


\section{References:}

1. Subrahmanyam M, Topical application of honey in treatment of burns, British Journal of Surgery, April 1991; 78(4); 497-498

2. Artz and Curtis P, Burns update, The Journal of trauma Injury infection and Critical care, 1976; 16(1); 3-15

3. Yamauchi K, Tomita M, Gielh T J and Ellison R T, Anti bacterial activity of lactoferrin and pepsin derived lactoferrin peptide fragment, Infection and immunity, American society of Microbiology, 1993; 61(2); 719-728

4. Antarkar DS, Chinwalla Tasneem, Bhatt Narendra, Anti-inflammatory activity of Rubia cordifolia Linn in rats, Indian Journal of Pharmacology, 1983; 15(3); 185-188

5. Shivakumar, An experimental study on the efficacy of Madhuchistadi Ghritha and Madhu in the management of Dagdha vrana, Dept of P G studies in dept. of Shalya tantra, 1992, Thesis work, G C I M, Banglore.

6. Mamatha murthy, A clinical study on the efficacy of Madhuchistadi gritha and madhu in the management of Dagdha vrana, Dept of P G studies in dept. of Shalya tantra, 1993, Thesis work, G C I M, Banglore.

7. Guruprsad, Woud healing activity of certain indigenous drugs, Dept of pharmacognacy, 1997, Thesis work, P.G Studies Govt college of pharmacy, Bangalore

8. Andrew $\mathrm{T}$ Rastery, Text book of surgery, Churchill livingstone, $2^{\text {nd }}$ Edition.

9. Burns trauma procedures, Clinical care by Chrissie Boswarth, $1^{\text {st }}$ Edition, London; Whurr publishers; 1998,

10. Mary M Wanger, Care of burn injured patient, London.Cason T S, Treatment of burns, London; Chapmen and Hall 

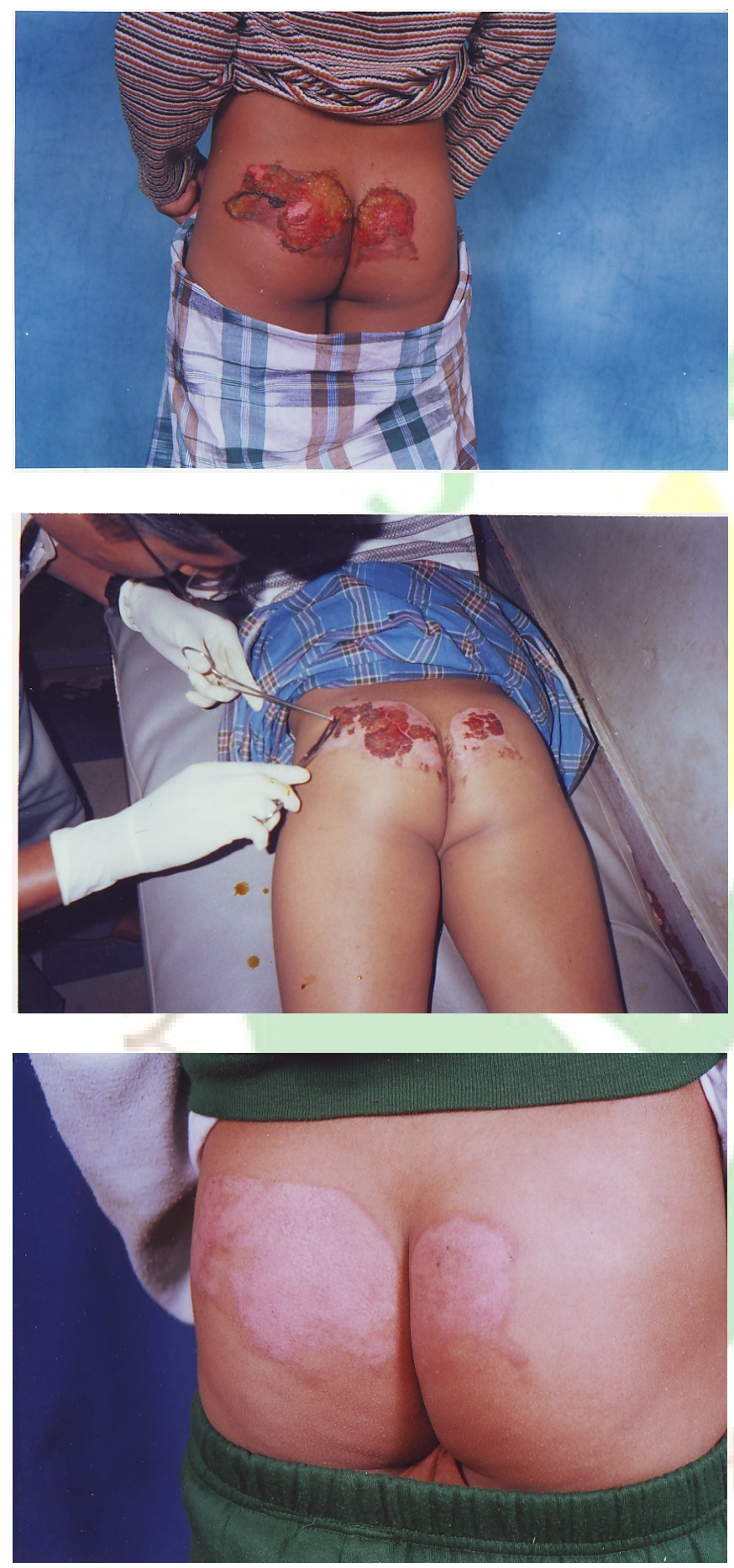

Figure 1: Before treatment, on day 1 of burn injury

Figure 2: During treatment on day 15

Figure 3: After the treatment, on day21 


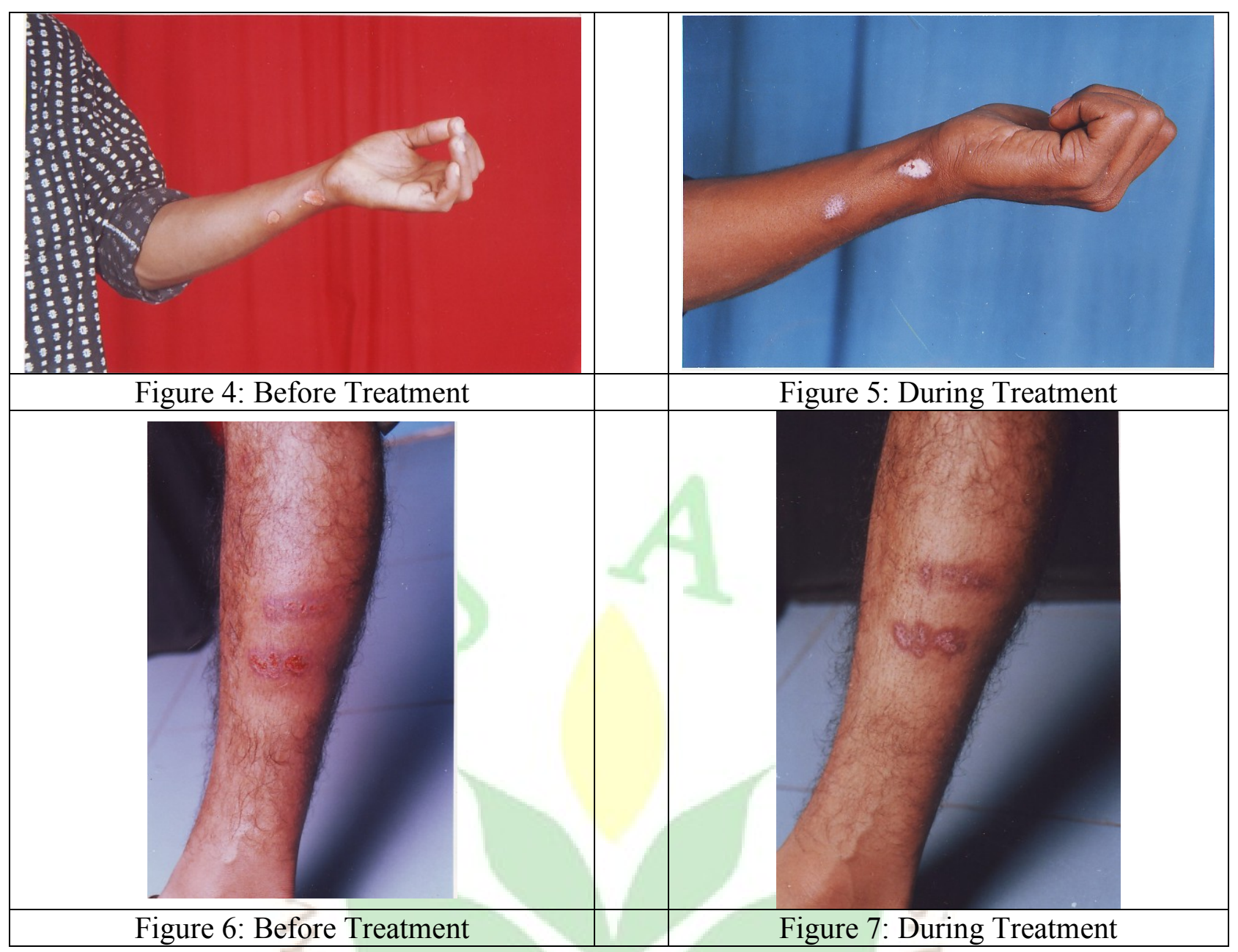




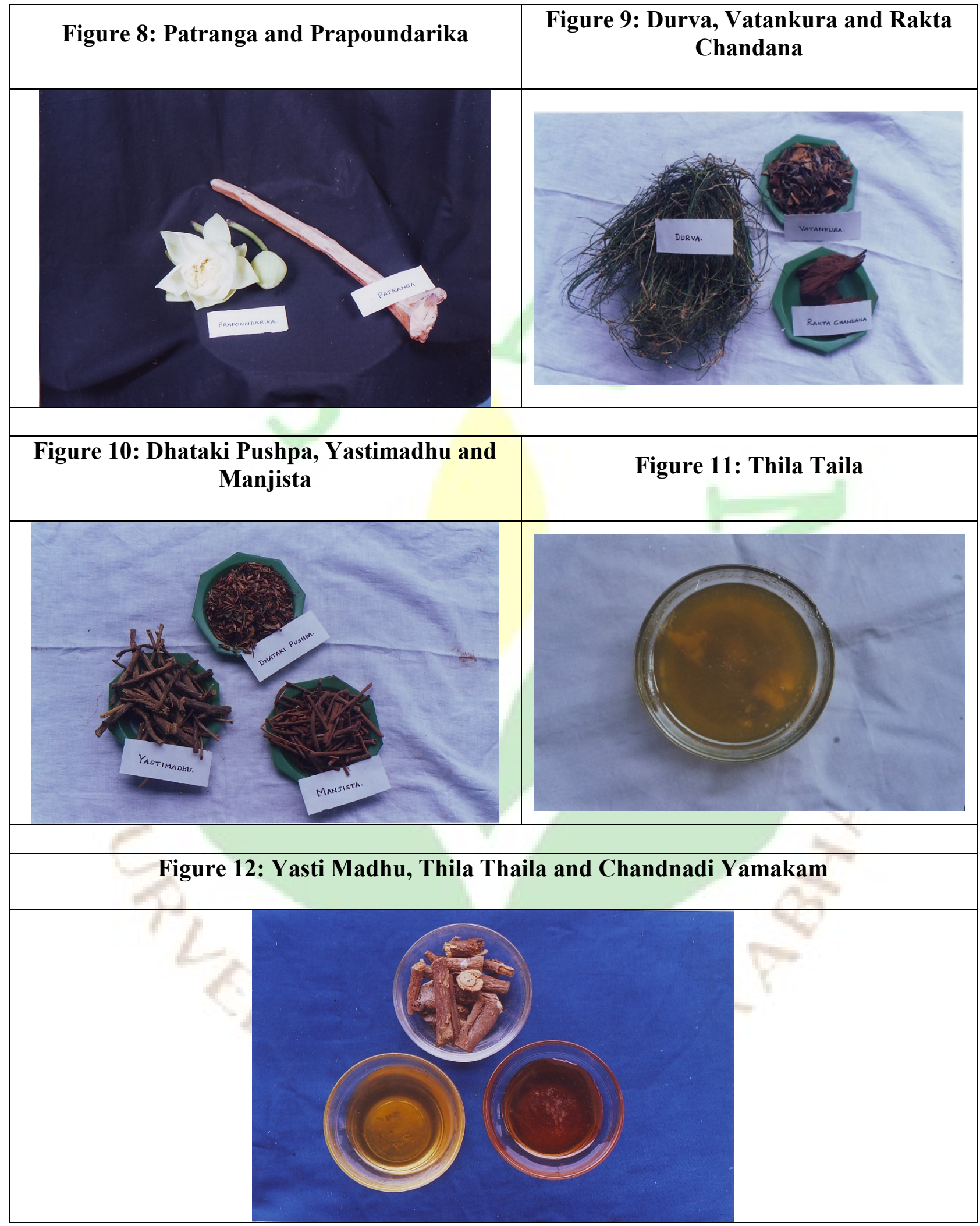

